九州大学学術情報リポジトリ

Kyushu University Institutional Repository

\title{
Propagation of Welsh Onion through Shoot Tip Culture
}

Fujieda, Kunimitsu

Horticultural Laboratory, Faculty of Agriculture, Kyushu University

Ando, Yukiko

Horticultural Laboratory, Faculty of Agriculture, Kyushu University

Fujita, Yukio

Horticultural Laboratory, Faculty of Agriculture, Kyushu University

https://doi.org/10.5109/23654

出版情報：九州大学大学院農学研究院紀要. 22 (1/2)，pp. 89-98，1977-10. Kyushu University バージョン：

権利関係 : 


\title{
Propagation of $\mathrm{W}$ elsh $\mathrm{O}$ nion through Shoot Tip Culture
}

\author{
Kunimitsu Fujieda, Yukiko Ando and Yukio Fujita \\ Horticultural Laboratory, Faculty of Agriculture, \\ Kyushu University 46-01, Fukuoka 812
}

(Received September 2, 1977)

\begin{abstract}
The application of a shoot tip culture to the problem of the multiplication of male sterile plants of Welsh onion was examined. Shoot tip explants of Welsh onion were grown on Murashige-Skoog medium containing various levels of kinetin and NAA under certain conditions. Formation of adventitious shoots or roots depended on the hormone levels used. Proliferation of adventitious shoots was the maximum in a medium containing $2 \mathrm{mg} / 1$ kinetin and $0.5 \mathrm{mg} / 1 \mathrm{NAA}$. Moderate temperature $\left(20^{\circ} \mathrm{C}\right)$ and long-day was optimal for adventitious shoot formation. Furthermore, formation of adventitious shoots was more active in explant isolated from stock plant which was more advanced in age. Adventitious shoots were rooted and grown into normal plants or were used to start new culture which formed more multiple shoots. The procedure for the transfer of the plantlets from nutrient media in aseptic containers to soil also was established.

This technique will be useful for multiplication of male sterile plants of Welsh onion and the practical seed production of $\mathbf{F}_{\mathbf{1}}$ hybrid will become possible by applying this technique to the multiplication of female parent.
\end{abstract}

\section{INTRODUCTION}

Male sterile mutant appears spontaneously at a considerably high frequency in Welsh onion (Nishimura and Shino, 1972). Unlike the case of onion, however, the genetic mechanism which controls the male sterility is complicated and a breeding technique for raising the male sterile strain has not been established as yet. Propagation of male sterile plant is possible to practise by division of the tiller shoots but the multiplication rate is low. In view of this, $F_{1}$ seed production of Welsh onion utilizing male sterility has not been put to practical use and furthermore, as other suitable crossing method has not been discovered, there is no possibility of utilizing heterosis in its breeding.

Micropropagation by tissue culture is regarded as a favorable method of vegetative propagation for plants which are difficult to propagate by current methods. The advantage of the technique is that it is possible to produce a large number of offspring, which in theory are identical, from a limited amount of parent material. It is for this reason that the technique has been applied to the propagation of orchids (Wimber, 1963; Reinert and More, 1967), carnations (Hackett and Anderson, 1967), asparagus (Takatori et al., 1968) and Chrysanthemum (Earle and Langhans, 1974). Furthermore, as inbred parent of cauliflower (Walkey and Woolfitt, 1970) and brussels sprouts (Clare and Collin, 1973) have been multiplied by tissue culture recently, attempts are being 
made on utilizing this for $F_{1}$ seed production. If a technique for multiplication of Welsh onion by tissue culture is established, the long-awaited practical seed production of $F_{1}$ hybrid will become possible by applying this technique to the multiplication of male sterile female parent.

The application of shoot tip culture technique to the multiplication of Welsh onion was therefore investigated for improved production.

\section{MATERIALS AND METHODS}

Field grown plants of the Welsh onion (Allium fistulosum L.), F ' Senju' $\mathrm{x}$ 'Kujoo', were used throughout as sources of cultured tissue. Seeds were sown in a plastic house on November 25th, 1975, and the seedlings were transplanted to a soil bed in an open field on February 26th, 1976.

To obtain explants from shoots the outer leaves were removed, and the exposed shoot, together with the adjoining disk tissue, was detached from the plant. The exposed shoot was surface-sterilized in 70 \% ethanol for 5 seconds, $0.5 \%$ sodium hypochlorite for 10 minutes and washed 3 times in sterile water. This material was trimmed to obtain the shoot tip explant. The explants isolated for culture contained the apical meristematic dome, a few leaf primordia and the adjoining disk tissue. The height of the explants ranged from 2 to 4 $\mathrm{mm}$. They were placed on the agar medium with the apex up.

The basal medium contained the Murashige-Skoog inorganic components (Murashige and Skoog, 1962), plus $0.1 \mathrm{mg} / 1$ thiamin $\cdot \mathrm{HCl}, 0.5 \mathrm{mg} / 1$ pyridoxine $\mathrm{HCl}, 0.5 \mathrm{mg} / 1$ nicotic acid, $2.0 \mathrm{mg} / 1$ glycine, $100 \mathrm{mg} / 1$ inositol, $30 \mathrm{~g} / 1$ sucrose and $7 \mathrm{~g} / 1$ agar. Kinetin and a-naphthaleneacetic acid (NAA) were added in the stated amounts. The $\mathrm{pH}$ of all media was set at 5.7 prior to agar addition and autoclaving. Test tubes, $24 \times 100 \mathrm{~mm}$, were used, and media were distributed in $10 \mathrm{ml}$ per tube. The tubes were sealed with a folded aluminium foil. Sterilization of media was achieved by autoclaving at $121^{\circ} \mathrm{C}$ for 15 minutes. Ten tubes were prepared of each test. Each tube of culture was inoculated with a single shoot tip explant.

\section{Production of plantlets}

The primary cultures budding many adventitious shoots were used as sources. The small sections with one or two shoots were cut from them, and each section was grown in $100 \mathrm{ml}$ Erlenmayer flask with $30 \mathrm{ml}$ test medium. The composition and preparation of the medium was treated in the same way as in the shoot tip culture.

\section{Preparation of plantlets for transfer to soil}

When the plantlets showed vigorous leaf and root development, each plant. let was removed from its flask and agar was washed away from the roots. Plantlets were then transferred to baked rice chaff in 'My Garden' (automatic solution culture equipment for home garden and its nursary bed is made by baked rice chaff; Sumitomo Kagakukogyo Co.) with the plastic film and net covers. The 'My Garden' were placed in plastic house. After 1 week under 
the covers, the plantlets were hardened by removing the covers for 2-3 hours each day for a week then the covers were removed altogether.

\section{RESULTS}

\section{Development of adventitious shoots}

a. Effects of kinetin and NAA

Kinetin and NAA were examined in these concentrations, in $\mathrm{mg} / \mathrm{l}:$ kinetin, $0,1.0$ and 2.0; NAA, 0, 0.1, 0.5 and 1.0 (Fig. 1).

Explants were placed on the media on November 25 th, 1976. All cultures were maintained under a $12 \mathrm{hr}$ light regime (circa 3000 lux from National Hilight FLR $40 \mathrm{D} / \mathrm{M}$ ) at $20^{\circ} \mathrm{C}$. After 40 days the percentage of explants with roots and the number of adventitious shoots per explant were determined. The results are shown in Figure 1.

Formation of adventitious shoots in explant took place on media containing kinetin. Significant differences in the number of adventitious shoots were not observed between the medium containing I $\mathrm{mg} / \mathrm{l}$ and $2 \mathrm{mg} / \mathrm{l}$ kinetin. Furthermore, on media in which NAA were present together with kinetin, a tendency of enhancement of shoot formation was indicated proportionally to the concentration of NAA up to the range of $1 \mathrm{mg} / 1$ tested.

On the other hand, formation of root in explant took place only on media containing no kinetin. NAA alone resulted in increasing the number of roots per explant with increasing concentration, but at the higher NAA concentration these roots were thickened.

\section{b. Effects of temperature}

Explants were placed on media containing $0.1,0.5$ or $1.0 \mathrm{mg} / 1 \mathrm{NAA}$ and 2

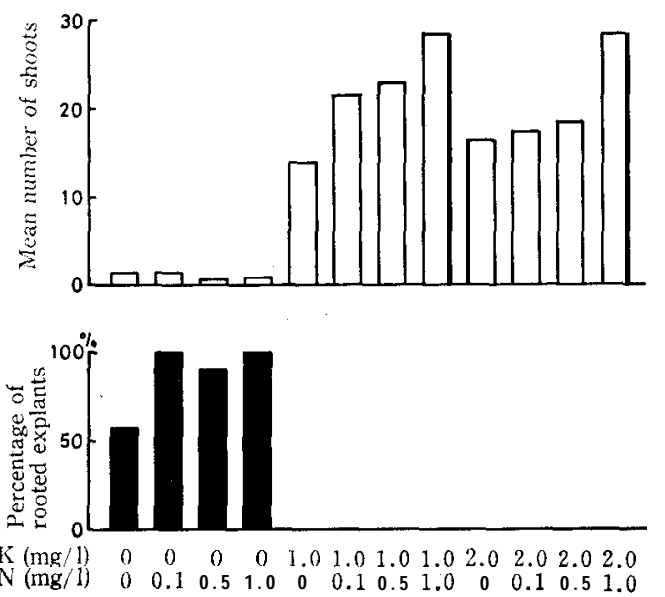

Fig. 1. Effects of kinetin (K) and NAA (N) on adventitious shoot and root formation. The shoot tip explants were cultured for 32 days on Murashige-Skoog medium with different kinetin and NAA levels. 
mg/l kinetin on August 13 th, 1976. The cultures were maintained under a 12 hr light regime (circa 3000 lux) at 20 or $25^{\circ} \mathrm{C}$.

On the 10 th day after isolation of the shoot tip, formation of adventitious shoots in the explant became visible in all trials. After this the number of shoots per explant increased rapidly, but the rate of increase became slow after 25 days. As shown in Figure 2, the increasing rates of shoots were somewhat larger at $20^{\circ} \mathrm{C}$ than at $25^{\circ} \mathrm{C}$ when explants were incubated on media containing $0.5-1.0 \mathrm{mg} / 1 \mathrm{NAA}$ and $2.0 \mathrm{mg} / 1$ kinetin.

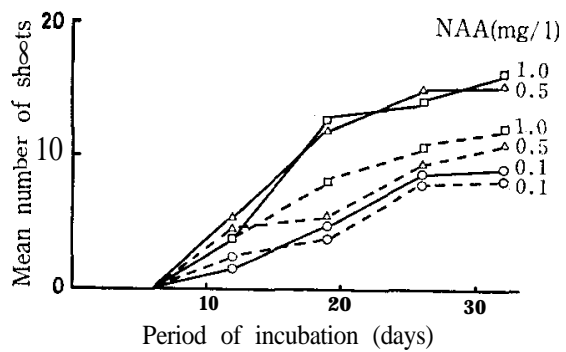

Fig. 2. Effect of incubation temperature on adventitious shoot formation. The shoot tip explants were cultured on Murashige-Skoog medium with 2.0 $\mathrm{mg} / 1$ kinetin and three NAA levels at 20 (solid line) and $25^{\circ} \mathrm{C}$ (broken line). The concentrations of NAA are indicated on the right side,

\section{c. Effects of day-length}

Explants were placed on the media containing $0.5 \mathrm{mg} / 1 \mathrm{NAA}$ and $2 \mathrm{mg} / 1$ kinetin on December 16 th, 1976. The cultures were maintained under a 12 $\mathrm{hr}, 16 \mathrm{hr}$ or continuous light regime (circa $3000 \mathrm{lux}$ ) at 20 or $25^{\circ} \mathrm{C}$. After 40 days the number of adventitious shoots per explant was determined.

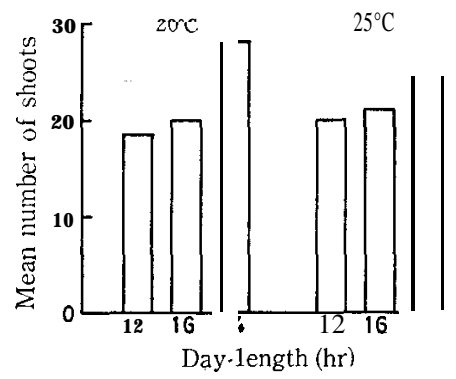

Fig. 3. Effect of day-length on adventitious shoot formation. The shoot tip explants were cultured for 40 days on Murashige-Skoog medium with 2 $\mathrm{mg} / \mathrm{l}$ kinetin and $0.5 \mathrm{mg} / 1 \mathrm{NAA}$ at 20 and $25^{\circ} \mathrm{C}$.

As shown in Figure 3, the multiplication of adventitious shoots was most enhanced under a continuous light regime, next in order was a $16 \mathrm{hr}$ and a 12 hr.

d. Effects of growth stage of stock plant

The shoot tip explants were isolated for culture at three different growth stages of stock plant. The three stages were as follows: pre-tiller stage (June 
17th), tiller stage (August 13 th) and flower bud differentiation stage (December 16th). Explants were placed on media containing $0.1,0.5$ or $1.0 \mathrm{mg} / 1 \mathrm{NAA}$ and $0,1.0$ or $2.0 \mathrm{mg} / 1$ kinetin. The cultures were maintained under a 1 ' $2 \mathrm{hr}$ light regime (circa 3000 lux) at $20^{\circ} \mathrm{C}$. After 32 days the percentage of cultures with roots and the number of adventitious shoots per explant were determined. The results are shown in Figure 4.
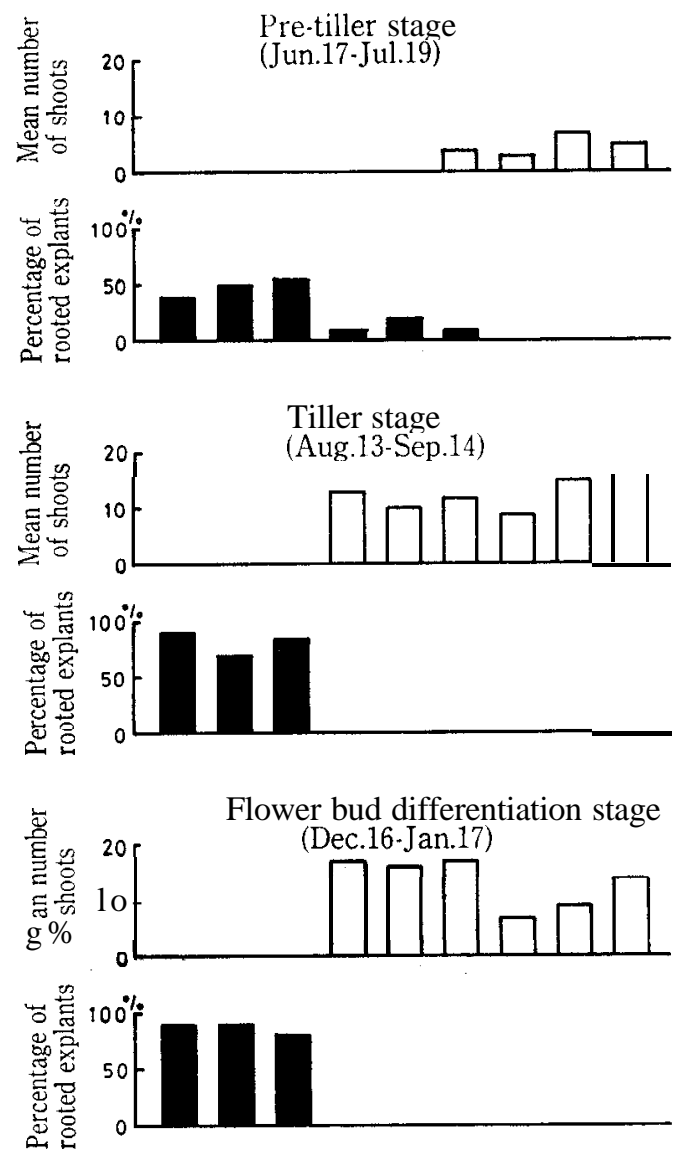

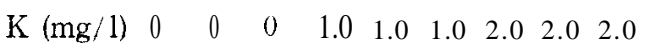

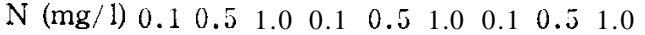

Fig. 4. Effects of growth stage of stock plant on adventitious shoot and root formation. The shoot tip explants were cultured on Murashige-Skoog medium with different kinetin $(\mathrm{K})$ and NAA $(\mathrm{N})$ levels.

Formation of adventitious shoots was more active in culture isolated from stock plant which was more advanced in age. That is, on media containing 1 $\mathrm{mg} / 1$ kinetin, the simultaneous presence of NAA was necessary for adventitious shoot formation in case of explant isolated from plant of the pre-tiller stage. Also, adventitious shoots were formed in all trials containing kinetin in case 
of explant from the tiller stage and the number of adventitious shoots per culture was larger than in the respective trials of pre-tiller stage. The formation of adventitious shoots was more active on media containing $2 \mathrm{mg} / 1$ than 1 $\mathrm{mg} / 1$ kinetin. Furthermore, proliferation of adventitious shoots was the maximum on a medium containing $1 \mathrm{mg} / 1$ kinetin in explant from the flower bud differentiation stage. In that case, NAA added had no effect on shoot formation even with increasing concentration.

NAA alone resulted in root formation and no shoots, but in case of explant isolated from plant of the pre-tiller stage, the percentage of explant with roots was smaller than them from the tiller and the flower bud differentiation stages.

\section{Production of plantlets}

The divided sections with one or two adventitious shoots were transferred on media containing 0 or $0.1 \mathrm{mg} / 1 \mathrm{NAA}$ and 0 or $0.5 \mathrm{mg} / 1 \mathrm{kinetin}$. These cultures were maintained under a $12 \mathrm{hr}$ light regime (circa $3000 \mathrm{lux}$ ) at 20 or $25^{\circ} \mathrm{C}$.

The test was repeated 2 times, from July 22nd to August 11th and from September 15th to October 9th, 1976. The adventitious shoots grew rapidly when transferred to new media and roots were formed in 80 percent and over of the sections after 20 days in almost all trials (Fig. 5). With respect to medium, the roots became thick and short on media containing kinetin and this tendency was further enhanced in a medium to which NAA had also been added. Most satisfactory plantlets were produced in the absence of both growth substances. With regard to the incubation temperature, the shoots of the plantlet appeared to be fresher at $20^{\circ} \mathrm{C}$ than $25^{\circ} \mathrm{C}$ and formation of roots also was satisfactory.

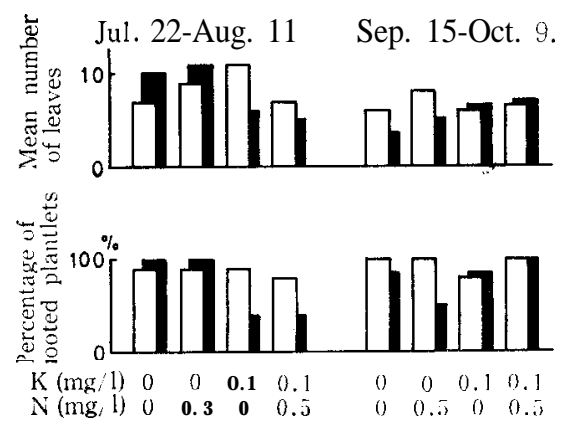

Fig. 5. Effects of kinetin (K), NAA (N) and incubation temperature on plantlet production. The adventitious shoots were cultured on MurashigeSkoog medium with or without $0.1 \mathrm{mg} / 1$ kinetin and $0.5 \mathrm{mg} / 1 \mathrm{NAA}$ at 20 (white column) and $25^{\circ} \mathrm{C}$ (solid column).

\section{Preparation of plantlets for transfer to soil}

Plantlets regenerated on media containing 0 or $1 \mathrm{mg} / 1 \mathrm{NAA}$ and 0 or $2 \mathrm{mg} / \mathrm{l}$ kinetin were used as materials in this test. All plantlets transferred to 
Tissue Culture of Welsh O nion

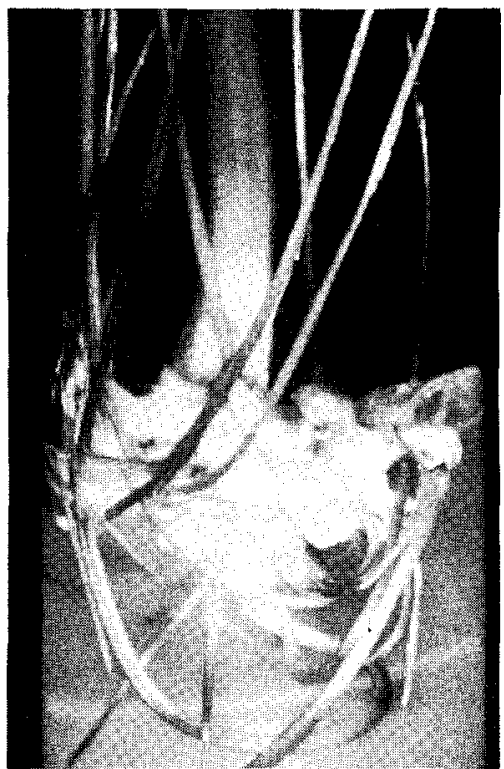

Fig. 6. Adventitious shoots formed on shoot tip explant. The explant cultured for 30 days on Murashige-Skoog medium with $2 \mathrm{mg} / \mathrm{l}$ kinetin and $0.5 \mathrm{mg} / \mathrm{l}$ NAA.

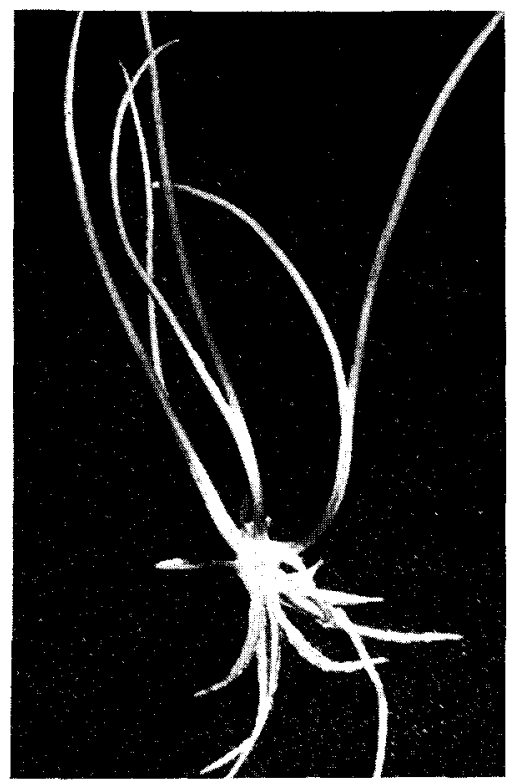

Fig. 7. Plantlet produced from divided adventitious shoot. The divided adventitious shoot cultured for 20 days on Murashige-Skoog medium without the hormones. 
'My Garden' grew healthily irrespective of the kind of medium on which the plantlets were produced. All plants tillered to 4-5 shoots. Seedlings divided into one shoot each were transplanted to soil and all of them matured normally.

\section{DISCUSSION}

A sexual multiplication through callus cultures is now possible in many genera. It has also been shown that a high frequency of plants derived from callus deviated genetically from the original plants in Liliaceae, such as edible asparagus, Asparagus officinalis, and Wakegi, Allium wakegi (Murashige and Nakano, 1966; Malnassy and Ellison, 1970; Shimada et al., 1973). To avoid genetically aberrant plants our efforts were turned toward the formation of multiple plantlets directly from a single shoot tip.

The technique of shoot tip culture of Welsh onion obtained from the present series of experimental results can be summarized as follows. 1) The shoot tip is placed in Murashige-Skoog medium containing $2 \mathrm{mg} / 1$ kinetin and $0.5 \mathrm{mg} / \mathrm{l} \mathrm{NAA}$ and the culture is kept in a long-day regime at $20^{\circ} \mathrm{C}$ for 30 days. Ten-odd of adventitious shoots will form in the culture by this porcess (Fig. 6). 2) Each of these shoots is isolated onto Murashige-Skoog medium containing no growth hormone and the culture is kept in a long-day regime at $20^{\circ} \mathrm{C}$ for 30 days. Up to that time, the divided shoot forms roots on the base and grows into plantlet that can be removed from the container (Fig. 7). 3) The

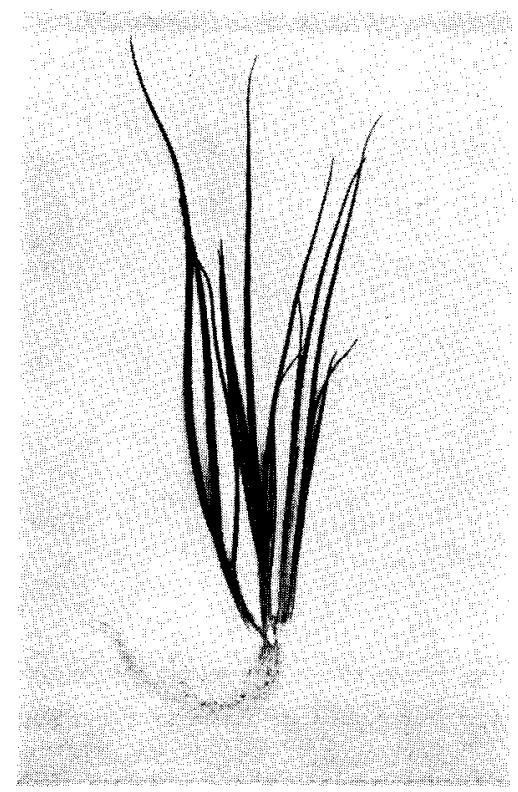

Fig. 8. Plantlets after the hardening-off stage. The plantlet removed from flask and grown for 30 days in 'My Garden' under plastic house condition. 
plantlet is removed from the container, transferred to a bed made of baked chaff and grown with a nutrient solution. The plant is tillered into 4-5 shoots after 30 days and when these divide, 4-5 seedlings which can be transplanted to the soil can be obtained from 1 plant (Fig. 8).

It therefore means that about 40 seedlings can be obtained from 1 shoot tip in about 90 days. It was also confirmed that several adventitious shoots which could be divided could be regenerated after about 25 days when subculture of the adventitious shoot was carried out on a medium containing kinetin and NAA. The number of shoots can be increased rapidly by repeating such subculture of adventitious shoots.

Adventitious shoot formation was strongly dependent on the presence of cytokinin in the present investigation, while auxin only had a modifying effect on the cytokinin influence. Similar conclusion was reached by Fonnesbech (1974) for tissue culture of Begonia x cheimantha. It was also shown by Earle and Langhans (1974) that application of high level of cytokinin to the base of the shoot tip explant of Chrysanthemum morifolium acted as a 'chemical pinch' causing the formation of multiple shoots.

As stated above, the presence of high level of cytokinin in medium strongly stimulated the multiplication of adventitious shoots but completely inhibited the initiation of roots. These shoots could be excised and, if placed back on the same medium, adventitious shoots reformed. If, however, the shoots were placed on the medium with the hormones omitted root and leaf formation was stimulated so that a plantlet was formed.

Several tens of Welsh onion plants multiplied by shoot tip culture were grown in the field. All of them matured normally and plants in which genetical aberration was indicated were not observed among them. Detailed studies, however, must be carried out in the future on plants regenerated from shoots by repeated subculture using a medium containing kinetin. If genetical aberrant plants do not appear in clone regenerated in such a manner, there will be possibility of establishment of economic $F_{1}$ seed production of Welsh onion by applying this technique to the multiplication of male sterile parents. As Welsh onion can be multiplied further in vivo by division of tiller shoots, its realization is a large possibility.

\section{ACKNOWLEDGEMENT}

The authors wish to express their gratitude to Dr. Shunpei Uemoto, Professor at Kyushu University, for his helpful suggestions and for reading the manuscript.

\section{REFERENCES}

Clare, M. V. and H. A. Collin 1973 Meristem culture of brussels sprouts. Hort. Res,, 13: 111-118

Earle, E. D. and R. W. Langhans 1974 Propagation of Chrysanthemum in vitro. 1. Multiple plantlets from shoot tips and the establishment of tissue cultures. J. Amer. Soc. Hort. 
Sci., 99: 128-132

Fonnesbech. M. 1974 The influence of NAA, BA and temperature on shoot and root development from Begonia $x$ cheimantha petiole segments grown in vitro. Physiol. Plant.. 32: $49-54$

Hackett, W. P. and J. M. Anderson 1967 Aseptic multiplication and maintenance of differentiated carnation shoot tissue derived from shoot apices. Proc. Amer. Soc. Hort. Sci, $90: 365-369$

Malnassy, P. and J. H. Ellison 1970 Asparagus tetraploids from callus tissue. HortScience, 5: 444-445

Murashige, T. and R. Nakano 1966 Tissue culture as a potential tool in obtaining polyploid plants. J. Heredity, 57: 114-118

Murashige, T. and F. Skoog 1962 A revised medium for rapid growth and bioassays with tobacco tissue cultures. Physiol. Plant., 15: 473-497

Nishimura, T. and M. Shino 1972 Studies on the male sterility in Welsh onion. I. Cytological studies. Abstract, Spring Assembly, Jap. Soc.Hort. Sci., pp. 180-181 (in Japanese)

Reinert, R. A. and H. C. More 1967 Propagation of cattleya by tissue culture of lateral bud meristems. Proc. Amer. Soc. Hort. Sci., 91: 664-671

Shimada,T.,S. Miyazaki, H. Tashiro and T. Ito 1973 Studies on the breeding of polyploid plant through tissue culture. 2. Chromosome survey in the culture of shoot apex of Wakegi (Allium wakegi). Abstract. Autumn Assembly, Jap.Soc. Hort. Sci.. pp. 154155 (in Japanese)

Takatori, F. H., T. Murashige and J. I. Stillmann 1968 Vegetative propagation of asparagus through tissue culture. HortScience, 3: 20-22

Walkey, D. G. A. and J. M. G. Woolfitt 1970 Rapid clonal multiplication of cauliflower by shake culture. J. Hort. Sci., 45: 205-206

Wimber, D. E. 1963 Clonal multiplication of cymbidiums through tissue culture of the shoot meristem. Amer. Orchid, Soc. Bull., 32: 105-107 